\title{
Using ATMs as Workload Relievers for Ghanaian Bank Tellers: The Customer Behavioral Challenge
}

\author{
${ }^{1}$ Mohammed-Aminu Sanda*, ${ }^{2}$ Eric Arhin \\ ${ }^{1}$ Division of Industrial Work Environment, Department of Business Administration, Technology and Social \\ Sciences, Luleå University of Technology, SE 97187 Luleå \\ 2Department of Organization and Human Resource Management, University of Ghana Business \\ School, PO Box LG 78, Legon, Accra, Ghana \\ *mohami@ltu.se
}

\begin{abstract}
This study explored the issue of whether the use of the Automated Teller Machines (ATM) as a service delivery tool in the banking industry of many developing countries has achieved its intended objective of increasing the effectiveness of customer service provision and reducing the workload of bank tellers. The purpose is to understand customers' behaviour towards the use of ATM as a banking service delivery tool, and the influence of such customer-usage behaviour on the banks' human resource capacity building, in terms of employee workload relief and performance. This is because most banks in subSaharan African countries have introduced the ATM in bids to satisfying customers' service needs and making the work of employees easier. Data was collected using questionnaires that were administered to bank customers who use the ATM facility, as well as bank managers. The findings showed that though most bank customers who use the ATM services perceive the ATM as a convenient, reliable, accurate and suitable service delivery tool for their banking transactions; they still underutilize the ATM's service capacity by choosing to go to the banking halls to make cash withdrawals of amounts that could be obtained from the ATMs. It is also found that by virtue of this customer behaviour of not using the ATM's to their full potential, the relief that it is expected to provide bank tellers is not realized. It is concluded that because of customer behavioral challenges to the effective utilization of the ATM technology, banks in developing economies not benefiting from its full potential as a customer service delivery tool, and also as a strategic workload reliever for tellers who service customers inside the banking halls.
\end{abstract}

Keywords: Automated teller machine; customer behavior; bank teller; workload reliever; developing economy

\section{Introduction}

The ability of most banks in most developing countries to deliver effective and satisfactory services to their clients remains a challenge as a result of the continued use of traditional approaches in the delivery of banking services. In this regard, such banks were faced with a situation where the functions of their employees and the traditional service delivery functions they offered were no longer their first interest. Instead such banks are increasingly depending on technology with their attendant quality issues (AlHawari, Ward, \& Newby, 2009). In bids to overcome this challenge, most of these banks have moved away from using traditional approaches in customer service delivery and have introduced information and communication technologies in their place to enable effective and satisfactory customer service delivery. Thus, the proliferation of new information and communication technologies within the financial industry has significantly influenced the way banks deliver services to their clients. Such technologies have enabled banks in developed economies to provide satisfactory customer services by enhancing their capacities to develop sophisticated products, design better market infrastructure, and implement reliable techniques for controlling risks. A semblance of this influence is highlighted by the introduction of selfservice technologies that have enabled banks to develop electronically mediated multi-channel service delivery platforms for clients. These platforms, which include the ATMs, telephone banking, Internet banking, and mobile banking, are efficient means for selling products and servicing customers. In this wise, the banking industry in many developing countries has experienced rapid legal and technological change. Among the many changes is the introduction of money counting machines and automated teller machines (ATM) to reduce workload and meet customer demands. This has simplified the operations of many banks, such as the counting of money by bank tellers and the manual recording of cash deposits. In bids to gain competitive advantage in the banking industry, many banks in the developing economies have introduced innovative banking products and services (such as the consumer credit scheme and the electronic funds transfer service) to their clients which interface with ATMs (as service delivery platforms). 
In Ghana, the number of firms in the banking industry at the time of independence in the year 1957 was three. This number has grown over the years to 23 financial institutions with a network of some 600 branches, 123 rural banks, and 13 savings and loans companies as in the year 2006. These banking firms operate alongside an array of non-banking financial institutions such as credit unions and mutual funds, insurance companies, and other micro-credit financial institutions. The banking industry is reasonably competitive and well capitalized, having withstood the pressures of rapid deflation over the past years. The banks could and ought to use information and communication technology platforms to develop competitive advantages. It is important that these platforms carry the capability of harmonization with the systems of other banks. In this regard the Ghanaian central bank issued guidelines for the operation of ATMs and Point of Sale Systems. For the bank customer, these electronic banking channels offer convenient access to bank accounts and eliminate the need to visit a bank's branch. Banks also benefit from self-service technologies as they can cut costs incurred by the traditional branch network (Hoehle \& Huff, 2009). However, the usage rates of these channels suggest that banks are missing out on the opportunity to attract more customers to the usage of electronic banking channels (Hoehle \& Huff, 2009). For example Meyer (2006) observed that though seventy-three percent of all European banking customers use ATM machines each month, only twenty-four percent of them use Internet banking services. Similarly, Ensor et al. (2007) noted that only five to ten percent of all consumers in North American and Australasian were found to have used the phone banking and mobile banking services offered them by their retail banks.

The issue of interest that arises from the observations made concern the issue of whether the use of the ATM as a service delivery tool in the banking industry of many developing countries has achieved its intended objective of increasing the effectiveness of customer service provision while reducing the workload of bank tellers and increasing their efficiencies remains unexplored. The financial services industry particularly the banking sector in Ghana from the year 2000 has experienced rapid legal and technological change. Among the many changes is the introduction of money counting machines and automated teller machines (ATM) to reduces workload and meet customer demands. This has simplified the operations of many banks (for example, the manual record of deposits and counting of money by bank tellers). However, it still remains to be answered whether the provision of automated teller machines has achieved its intended human resource and customer oriented competitive advantage objective, in terms of increased human resource efficiency and effectiveness as well as the effectiveness of customer service provision. In this respect, an answer to the following research question was explored: Does the introduction of ATM (as a new technology) by Ghanaian Banks influences customer behaviours towards service requirements, and by implication result in the reduction of employee workload and improvement in the efficiency and effectiveness of their service delivery in the banking halls?

The purpose of this study therefore, is to answer the question above by understanding customers' behaviour towards the use of ATM as a banking service delivery tool in Ghana, and the impact of such usage behaviour on the banks' human resource capacity building, in terms of employee workload relief and performance. In other words, the study investigated whether the provision of ATMs, as customer service points, reduces customers' need for direct service transactions with bank employees in the banking halls, and by implication, reducing the workloads of the employees and providing them opportunities for efficient and effective customer service deliveries in the banking halls.

\section{Literature Review}

In recent years, most banks in developing economies, especially in sub-Saharan countries, have sought to make their services convenient through electronic banking. The idea is to make work easy and increase reaction time among bank employees while at the same time satisfying customers' service needs. By viewing an organization as a social system with an economic purpose, the ways in which it uses its knowledge and other resources to achieve that economic purpose represent its strategies (Haberberg \& Rieple, 2001). Haberberg \& Rieple (2001) defined strategy as the set of actions through which an organization, by accident or design, develops resources and uses them to deliver services or products in a way which its users find valuable, while meeting the financial and other objectives and constraints imposed by key stakeholders. Haberberg \& Rieple (2001) argued that successful strategies give an organization some properties that are unique and the means for renewing its competitive advantage as the business environment changes. Johnson \& Scholes (1997) linked strategy to competitive advantage by noting that strategy is the direction and scope of an organization that provides it advantage over others through its configuration of resources in a changing environment to meet the needs of markets and fulfill 
stakeholder expectations. The strategy of an organization is therefore, affected not only by environmental forces and resource availability, but also by the values and expectations of those who have power in and around the organization (Johnson \& Scholes, 1997). In this regard, many firms in the banking industry of developing economies have undergone major technological changes aimed at improving the quality of banking products and services towards meeting customer needs, and keeping up with competition. As such, the uses of the internet together with the ATM represent significant developments in the application of technology to design strategic tools for banking operations. The ATM is an innovative customer service delivery tool that offers diversified financial services, such as cash withdrawal, funds transfer, cash deposits, and payment of utility bills, among other financial enquiries. Thus for technology-based delivery channels, such as the ATM, the satisfaction of users is an essential determinant of technological success of the (Wu \& Wang, 2007; Tong, 2009; Khan, 2010).

The use of the ATMs as customer service delivery interfaces has enabled bank customers to transact banking business using a coded ATM card. Wherever an ATM facility is located, customers can access their banks accounts for twenty four hours a day and seven days a week. A number of studies (e.g. Essinger, 1999; Fitzsimmons \& Seay, 2003; Zhu, Scheuermann, \& Babineauz, 2004) have shown that most banks do not only use the ATMs as a strategic tool for satisfying customer-oriented need, enhancing employees' efficiency, and gaining competitive advantage, they also use it to signify their technological advancement. In a study in which factors that impacted on the adoption of internet banking services were investigated, Tan and Thompson (2000) found that customers' attitude and perceived behavioral controlfactors significantly influenced their intentions to use internet banking services. Other studies have also investigated the acceptance of internet banking services (e.g. Suh \& Han, 2002; Lai \& Li, 2005; Cheng, Lam \&Yeung, 2006). For example, Suh \& Han (2002) observed that trust has a more direct effect on a customer's attitude than perceived ease of use in the internet banking context.

In most developing economies, the automation of banking services has become a critical factor in the process of attaining efficiency in delivering customer services. Many banks have pursued the development of technology-driven strategies towards meeting customer preferences. The ATM is one tool that has played a pioneering and pivotal role in advancing the technological transformation of banking. According to Leblanc (1990), the main reason for using ATMs was an accessibility factor. This factor involved the ATM users' perceptions of it being fast, easy to use, improving the quality of service, and reducing costs. The ATM technology has advanced faster than changes in the habits of customer (Stanley, 1983). In this regard, bank customers' perceptions of ATM attributes could be used as important indices by banks to develop ATM-related products and services that meet customer expectations. This is because the acceptance of service payments using ATM-enabled credit cards has been identified as useful and of strategic business value by firms in the service industries (such as restaurant), and also firms in the manufacturing sector (Stevens, Martin, Carter \& Cogshell, 1986). Stevens et al. (1986) suggested that ATM users who adopted this form of service payments as an integral part of their banking methods should obviously become the prime targets of any new ATM features and other automated banking innovations. This suggestion is based on the premise that the relationships between banks and their customers might change through the introduction of new technologies (Barnes, 1997).

Lewis, Ordledge and Mitchell (1994) outlined the major benefits of strong banking services to include the following; (i) satisfied and retained customers, (ii) opportunities for cross-selling, (iii) attraction of new customers, (iv) development of customer relationships, (v) increased sales and market shares, (vi) enhanced corporate image, and (vii) reduced costs and increased profit margins and business performance. These factors provided an important pathway that could be used to better understand the needs and expectations of consumers of banking products who could be profiled and segmented on the basis of their perceptions of ATM attributes. An assessment of bank customers' ATM usage patterns and perceptual variables by Joseph and George (2003) showed that ATMs were not being utilized to their full potentials and had largely not been accepted by some bank customers as innovations that could fully replace bank tellers in nominated functions. This observation is relates to the finding that technologybased services have the likelihood of inculcating in customers a sense of incompetence which tends to isolate them from the technology, and also increase their passiveness towards its usage (Grabner-Krauter \& Kalusha, 2003). In this regard, banks have not been able to capitalize on Zhu et al. (2004) postulated that a pleasant experience of automated services provides enhanced value to the customers and attract them in undertaking improved business with their banks. 


\section{Method and Materials}

Data Collection: Data was collected using questionnaires. The points of data collection were ATM centers and bank branches of a multinational bank in a sub-Saharan African country. There were two categories of respondents. These were the branch managers of the bank, and the bank's customers using ATM cards. In all 16 branches of the bank were selected and questionnaires administered to the respective branch managers. One hundred and twenty (120) bank customers were also randomly identified at ATM centers in close proximity to each of the sixteen bank branches. Items in the questionnaire administered to the bank customers were centered on their withdrawal patterns from the ATMs and in the banking halls, as well as on the following four factors of customers' ATM usage satisfaction: (i) convenience, (ii) reliability, (iii) accuracy, and (iv) suitability. The conveniences factor entailed six questions, while the reliability, accuracy and suitability factors entailed three questions each. The questionnaire administered to the bank managers revolved around two ATM banking-service application factors. These were; (i) the use of the ATM as a customer service delivery tool, and (ii) the use of the ATM as tool for gaining competitive advantage. The service delivery factor entailed ten questions, while the competitive advantage factor entailed four questions. The responses in the questionnaires were based on the five point Likert scale for both customers and managers. The customers' responses to the four factors of customers' ATM usage satisfaction were based on the summated Likert scale. The scoring for each item ranged from 10 (strongly disagree) to 50 (strongly agree). While customers took an average of ten (10) minutes to complete the questionnaire, the questionnaires from the bank officials took a maximum of three (3) days to retrieve.

Data Analysis: Data was analyzed using statistical package for the social sciences (SPSS) software. The customers withdrawal patterns using the ATMs, and from the banking halls were examined. Each of the customers' ATM usage satisfaction factors (i.e. convenience, reliability and accuracy) for using the ATM was also analyzed using the mean scores estimated from the respondents' summated scores for each factor. The mean scores were used to determine the respondents' collective perceptions of the strength or weakness of each of the customers' ATM usage satisfaction factors. The managers' assessment of ATM functionality as a customer service delivery tool, and as a tool for gaining competitive advantage in the banking industry was also examined.

\section{Results and Discussion}

Customers Behavioral Relationship with ATMs: The customers' cash withdrawal behaviours using the ATMs and the Banking halls are shown in figure 1 below.

Figure 1: Customers' Cash Withdrawal Pattern from the ATMS and the Banking Halls

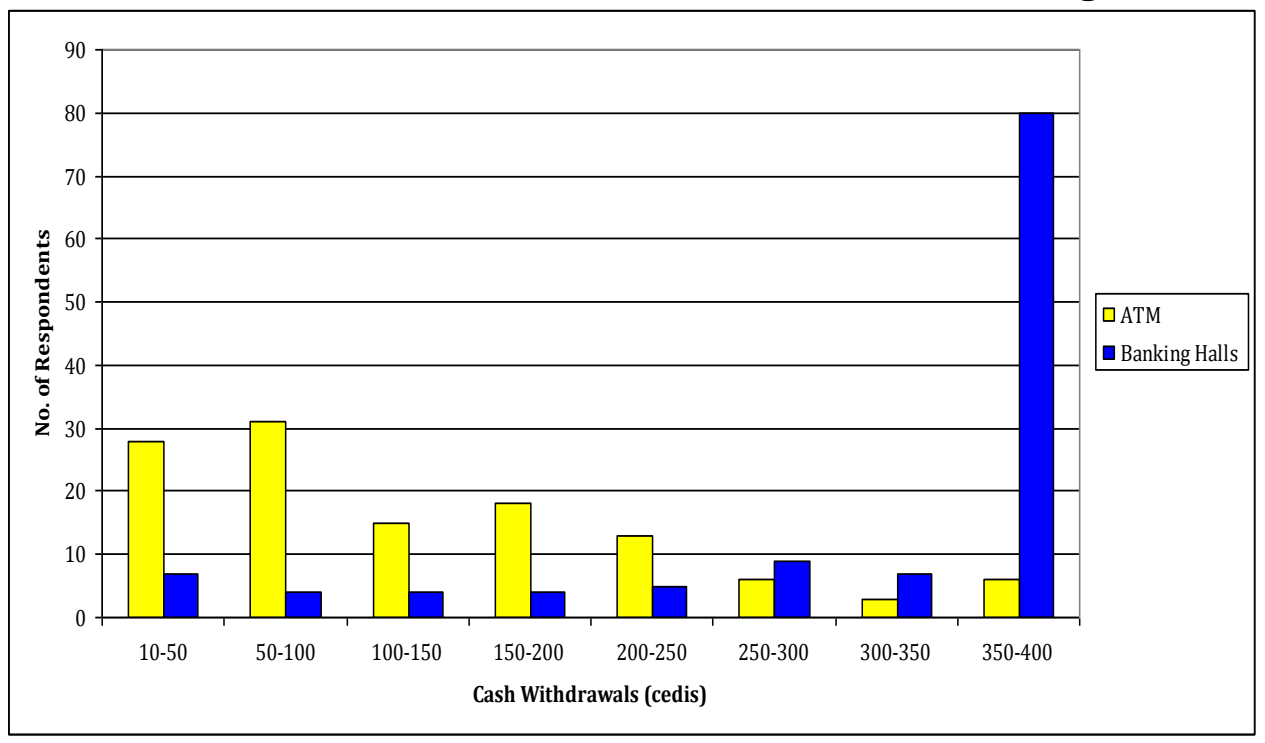

As it is highlighted in figure 1 above, analysis of the customers' cash withdrawal behaviours of amounts ranging from $\mathrm{GH} \$ 10$ to $\mathrm{GH} \$ 250$ shows that majority of customers, as indicated by 105 ( $87.5 \%$ ) of the 120 respondents, prefer to use the ATMs rather than going to the banking halls. But for withdrawals above GH\$ 250 up to a maximum of GH\$ 400 which can be done using the ATMs, only 15 (12.5\%) 
respondents indicate their preference of using it. This customer behaviour of limiting the capitalization of the maximal service capacity of the ATMs (i.e. limiting withdrawal to GH\$250 in comparison to the ATM's service capacity of GH\$ 400) is reinforced by the observation that majority of the customers, as indicated by $95(79 \%)$ of the respondents, will rather go to the banking halls for cash withdrawals than use the ATMs.

The implication from this analysis is that though most customers find the ATM as useful a service delivery tool, they tend to use it for only small withdrawals and then go to the banking halls for other withdrawal services for which the ATM is programmed by the banks to handle. By this customer behaviour, the ability of the ATM to serve as workload reliever to the tellers inside the banking halls is limited as a result of customers' underutilization of its potential and their continued dependence on tellers for services that the ATMs can provide. Such customer behaviour is probably influenced emotionally by a sense of affection that the customers have for the traditional service quality available in the banking halls. This sense of traditional service quality is a reflection of the customers' perceptual beliefs and/or attitudes that a better degree of service excellence is offered in the bank's physical location (Castleberry \& Resurreccion, 1989). This therefore shows that in the act of service delivery, the human element of service quality, which refers to all aspects of the interaction between staff and customers, play a vital role in shaping the overall customer perception of service quality (Mouawad \& Kleiner, 1996; Yavas, Bilgin, \& Shemwell, 1997). The customers' behaviour may also have been influenced by their desires to have direct contact with the bank employees. As Mouawad and Kleiner (1996) explain, employees have an important effect on customer service as they are the key element that customers interact with during the service encounter stage. Well trained employees are able to achieve high level of customer cognition as well as affection toward the organization they are dealing with (Schneider \& Bowen, 1995).

Customer Awareness of ATM Support Centers and Factors Influencing Usage: The issue of whether the bank customers are aware of ATM support-centers and whether they call for assistance when the need arises is investigated. The results shows that $90(75 \%)$ of the 120 customers surveyed are not aware of the existence of the banks' ATM support centers. This implies that majority of the customers are not aware of the ATM support centers. Only $30(25 \%)$ of the respondents indicate their awareness of the existence of the banks' ATM support centers. There is a significant variation in relation to the respondents' sources of awareness. Out of the 30 customers, 13 of them indicate direct knowledge of the establishment of the ATM centers. Eleven customers had the information from friends while 6 customers found out from the bank branches. Again, there is no significant difference in the responses between the female and male customers concerning where they had their information about the existence of the ATM support centers. The male customers appear to have direct knowledge of the establishment of the ATM centers while most of the female customers source their information from friends and the bank branches. The results also show that fifty percent of the 30 customers who indicate their awareness of the existence of the bank's ATM support centers have never called the ATM support centers for assistance or information. This is because they prefer going to the banking halls to solve their ATM problems rather than calling on the ATM support centers.

The result of customers' scores on the satisfaction factors influencing their use of the ATM is summarized in table 1 below. As it is indicated in table 1 above, an assessment of the convenience factor for the ATM's usage shows that, the mean score for the male customers is $M=20.27$ ( $S D=2.58$ ), and for the female customers, $\mathrm{M}=20.39$ ( $\mathrm{SD}=2.95$ ). This implies that both the male and female customers perceive the use of the ATMs as convenient. The scoring for the ATM's reliability shows that for the male customers, the mean score is $\mathrm{M}=8.45(\mathrm{SD}=2.20)$, and for the female customers, $\mathrm{M}=8.65(\mathrm{SD}=2.05)$. This implies that both males and females find the ATMs as a reliable tool. The scoring for the ATM's accuracy in service delivery shows that for the male customers, the mean score is $M=10.03(S D=2.36)$. For the female customers, the mean score is $\mathrm{M}=9.93(\mathrm{SD}=2.18)$. This implies that both males and females perceive the ATM's as being accurate in their service delivery. Concerning the ATM's suitability, the mean score for the male customers is $M=7.98$ ( $S D=2.41)$. For the female customers, the mean score is $M=8.70(S D=2.41)$. This implies that both males and females perceive the ATMs as suitable service delivery tools. 
Table 1: Mean Scores and Standard Deviations for the Customer Satisfaction Factors

\begin{tabular}{llccc}
\hline $\begin{array}{c}\text { Customer Satisfaction } \\
\text { Factors }\end{array}$ & Gender & N & $\begin{array}{c}\text { Mean Score } \\
\text { (M) }\end{array}$ & $\begin{array}{c}\text { Standard Deviation } \\
\text { (SD) }\end{array}$ \\
\hline Convenience & Male & 60 & 20.27 & 2.58 \\
& Female & 60 & 20.38 & 2.95 \\
Reliability & Total & 120 & 20.33 & 2.76 \\
& Male & 60 & 8.45 & 2.20 \\
\multirow{2}{*}{ Accuracy } & Female & 60 & 8.65 & 2.05 \\
& Total & 120 & 8.55 & 2.12 \\
& Male & 60 & 10.03 & 2.36 \\
\multirow{5}{*}{ Suitability } & Female & 60 & 9.93 & 2.19 \\
& Total & 120 & 9.98 & 2.27 \\
& Male & 60 & 7.98 & 2.41 \\
& Female & 60 & 8.70 & 2.42 \\
& Total & 120 & 8.34 & 2.43 \\
\hline
\end{tabular}

The implication from the results above is that; while there is no significant perceptual difference between the male and female customers on the use of ATMs, there is a slight variation in their ratings of the use factors. Both genders perceive their usage of the ATMs to be influenced firstly by its convenience, followed by its accuracy in service delivery. In addition to these two factors, the males perceive the ATM's reliability as a more influential factor than its suitability as a service tool. Conversely, the females perceive the suitability of using the ATM's as a more influential factor than its reliability as a service delivery tool.

The results show that banks in developing economies can exploit the use values of the ATM to enhance customer service delivery. As it is shown in the results, both male and female customers perceive ATM service delivery in order of its convenience, followed by its accuracy. While the female customers perceive the ATM's reliability and suitability to be at the same level, the males rank the ATMs performance, firstly in terms of its reliability and then its suitability. This means that the ATM usage is primarily to satisfy customers need (Moutinho \& Brownlie, 1989), and its users differ quite significantly in their perceptual ratings of its attributions (Regimbana \& Iversen, 1994). The results therefore, support Ibrahim, Joseph \& Ibeh's (2006) finding of the ATM's convenience, accuracy, reliability, and service personalization as important attributes that satisfy customers' usage. The result is also supported by Pyun, Scaggs and Nam's (2002) findings that most service providers such as banks move quickly to invest in technology as a way of controlling costs, attracting new customers, and meeting the convenience and technical innovation expectations of their existing customers. The implication here is that the ATM's functional convenience, efficient operation, security and privacy, reliability and responsiveness are not the only characteristics that influence customers' satisfaction also contribute to customer satisfaction (Ranaweera \& Prabhu, 2003; Khan, 2010). This means that quick response to customers' needs and queries about the ATM-related services are important for improving the service delivery standards of the ATM.

Arguing from Solomon, Surprenant, Czepiel \& Gutman's (1985) notion that role players should provide compatibility between expectation and perception during service encounter, banks should also facilitate a two-way communication system that will encourage customers' to view their participation in improving ATM service quality as a pleasant experience. In addition to this finding, the study reveals that no significant gender differences exist in customer perception of ATM usage. Howcroft, Hamilton \& Hewer (2002) note that consumers' preference for a mix of delivery channels will mean that electronic channels like telephone and internet banking may not be the dominant delivery channel. The use of the banking halls is still the most preferred service delivery channel for most customers. A possible explanation of the customers' preference of going to the banking halls may be that; the absence of direct interaction with bank staff when using the ATM tends to increase their perceptual apprehensions about transactional risk (Grabner-Krauter \& Kalusha, 2003). Such customers' perception of the ATMs is formed by their concerns over transactional security and privacy issues with the ATM. The banks can alleviate such customer apprehension by improving the ATM service quality, as well as the quality of interaction between the ATMs and customers (Merrilees, 2002; Khan, 2010). However, duplication of delivery channels will result in increasing costs and banks will have to educate consumers and encourage them to use more of the 
customer-services provided by technological tools, such as the ATM, and also by means of telephone and Internet banking.

In order to be cost effective and successful in implementing telephone and Internet banking, banks will need to provide value for money, error free, convenient and user-friendly services. Banks that excel in quality service can have a distinct marketing edge since improvement in the level of service quality is related to higher revenues, increase in cross-sell ratios, and higher customer retention (Bennett \& Higgins, 1988) and expanded market share (Bowen \& Hedges, 1993). Similarly, Easingwood \& Storey (1993) report that total quality is the most important factor in the success of new financial services, while Bennett \& Higgins (1988) believe that a competitive edge in banking originates almost exclusively from service quality. The preference of bank customers' to use the ATM because of its multifaceted attributes has placed pressure on banks to respond to these needs. The study provides learning that can be used by the banks to improve the quality of ATM service, and subsequently increase customers' satisfaction. As Khan (2010) argues, the focus must not be on only the service quality dimensions of the ATM, but also on the augmentation and integration of other aspects of banking service delivery in order to derive customers' satisfaction.

Managers Assessment of ATMs' Service Functions : The result of the bank managers' assessment of the ATM functionality as a service delivery tool shows that majority of them $(81.25 \%)$ perceive the ATM as a service delivery tool that can be used to effectively enhance banking transaction performance while reducing the workload on tellers providing services in the banking halls. With the exception of 3 managers who are unsure in their assessment, none of them disagree to the importance of the ATM as a service delivery tool. The distribution of the managers' assessment is shown in figure 3 below. The result of the bank managers' assessment of the notion that the ATM can be used as a tool to gain competitive advantage in the Ghanaian banking industry shows that they are all in disagreement. While 9 (56.25\%) of the managers disagree that the ATM is a tool that can be used to gain competitive advantage, 7 (43.75\%) of them are rather quite strong in their disagreement.

As it is indicative from the results above, the managers view the ATM as a tool that can be used to enhance customer service delivery. This view supports Leblanc's (1990) finding that the main reason for using ATMs is an accessibility factor involving the perceptions of being fast, easy to use, improving the quality of service, and reducing costs. As Lewis et al. (1994) notes, managers in virtually all industries understand that providing quality customer service is a key strategic component in firm profitability. The managers agreeing to the notion that ATM helps clients banking needs, cut down long queues in the banking halls, and allow banking officials more time to interact with customers, show that the ATMs can be used to enhance service delivery and banks corporate images towards improved sales and market share. This finding is consistent with Leonard \& Spencer's (1991) observation that a great majority of consumers perceived banks with ATMs as being either very successful or somewhat successful. It also relates to Essinger's (1999) argument that the role of technology in today's international financial community has changed significantly and is not only assisting with keeping record, but is also powering delivery systems, trading decisions, support systems and clearing and settlement systems.

The perception of the managers that the ATM cannot be used as tool for gaining competitive advantage in the Ghanaian banking industry can be related to the banks' inability to ensure sustained maintenance quality performances of the ATM technology. This is because earlier studies (e.g. Essinger, 1999) have shown that new technological solutions, such as the ATMs, can be employed to win new businesses and improved customer retention. In this regard, the banks must monitor the environment and identify the trends through marketing intelligence. There is the need to differentiate constantly and update the ATM service quality dimensions to ensure continuous satisfaction and retention of customers (Khan, 2010). Furthermore, there is the need to improve the quality of the ATM customer service delivery by enhancing its interactivity, and diversifying its service offering so as to make its usage a memorable and pleasant experience for bank customers. In this regard, banks must bid to retain ATM users compliment by providing services that will appear not only satisfying, but also delightful to the customers. In order to enhance this, the banks need to capitalize on the spread of communication technology and the theory of innovations (Marshall \& Heslop, 1988), and also develop strategies to motivate non-ATM users through awareness, education, extending personalized services, and demonstrating the functions of ATMs (Khan, 2010). In order words, Ghanaian banks are capable of using the ATM technology to create dynamic business systems that could be used to win businesses and thus achieve competitive advantage. As Bennett and Higgins (1988) note, a competitive edge in banking originates almost exclusively from 
service quality, and banks that excel in quality service can have a distinct marketing edge since improved levels of service quality are related to higher revenues, increased cross-sell ratios, higher customer retention and expanded market share.

\section{Conclusion and Recommendations}

This study has shown that Ghanaian bank customers who use the ATM services perceive the ATM as convenience, reliable, accurate and suitable for their banking transactions, which fall in line with the views of other researchers. The study also revealed that ATM can be used to enhance customer service delivery, which could also pave the way for the reduction of the workload on tellers in banking halls. Such workload reduction could provide the tellers with opportunities for adequate interaction with customer and also help improve their functional efficiencies and effectiveness in customer service delivery. The study has therefore shown that improving the service quality of the banking with the ATM could improve the overall customer perception of the ATMs functional suitability for service provision as rendered by tellers in the banking halls. This is because most bank customers have come to accept electronic banking services as augmenting the normal delivery services provided by bank tellers. It is therefore concluded that because of customer behavioral challenges to the effective utilization of the ATM technology, banks in developing economies not benefiting from its full potential as a customer service delivery tool, and also as a strategic workload reliever for tellers who service customers inside the banking halls.

This research is relevant for the reason that it has provided both practical and theoretical insights into challenges of using the ATM technology as a customer service delivery tool. This is in relation to how customer-usage behaviours impacted on the applicability of the ATM as a strategic tool for reliving bank tellers of their workloads. The findings on customer behaviours towards the ATM usage could be used to strategize and sustain customers' interest and support in the usage of the ATMs and which achievement could help relive the workload of tellers servicing other customers in the banking halls. The outcome of this research contributes to the sum total of knowledge in the study and practice of using technological tools to influence consumer behaviours towards enhancing employee efficiency and effectiveness in the field of strategic human resource management. Specifically, for Ghana, this research provides a platform for the development of a database that will help inform policy-makers on the requisite behavior to be required of bank clients in the introduction of new customer service technologies. Focusing the study on the ATM usage for one bank alone is a limitation, since a study of other banks could also have provided data with a broader perspective, and which could have had an impact on the results obtained.

\section{References}

Al-Hawari, M. Ward, T. \& Newby, L. (2009). The Relationship between Service Quality and Retention within the Automated and Traditional Contexts of Retail Banking. Journal of Service Management, 20(4), 455-472.

Barnes, J. (1997). Closeness, Strength, and Satisfaction: Examining the nature of relationship between providers of financial services and their retail customers. Psychology \& Marketing, 14(8), 765-90.

Bennett, D. \& Higgins, M. (1988). Quality Means More Than Smiles. ABA Banking Journal, 80(6): 46.

Bowen, J. W. \& Hedges, R. B. (1993). Increasing Service Quality in Retail Banking. Journal of Retail Banking, 15(3), 21-28.

Castleberry, S. \& Resurreccion, A. (1989). Communicating Quality to Consumers. Journal of Consumer Marketing, 6(3), 21-89.

Cheng, T. C. E., Lam, D. Y. C. \& Yeung, A. C. L. (2006). Adoption of Internet Banking: An Empirical Study in Hong Kong. Decision Support Systems, 42(3), 1558-1572.

Easingwood, C. J. \& Storey, C. D. (1993). Marketplace Success Factors For New Financial Service. Journal of Services Marketing, 7(1), 41-54.

Ensor, B. Hesse, A. de Lussanet, M. van Veen, N. \& Menke, L. (2007). European Mobile Banking: An Inconvenient Truth. Cambridge, MA: Forrester Research Inc. http://www.banklounge.de/pdf (Accessed 26th April, 2011).

Essinger, J. (1999). The Virtual Banking Revolution: The Customer, the Bank and the Future. London: Thomson Business Press.

Fitzsimmons, J. A. \& Seay, W. H. (2003). Is Self-Service the Future of Services? Managing Service Quality, 13(6), 443-444.

Grabner-Krauter, S. \& Kalusha, E. (2003). Empirical Research in On-Line Trust: A Review and Critical Assessment. International Journal of Human-Computer Studies, 58(6), 783-812. 
Haberberg, A. \& Rieple, A. (2001). The Strategic Management of Organization. Harlow, Essex: Pearson Education.

Hoehle, H. \& Huff, S. (2009). Electronic Banking Channels and Task-Channel Fit. In ICIS 2009 Proceedings (paper no. 98). http://aisel.aisnet.org/icis2009/98 (Accessed 26th April, 2011).

Howcroft, B. Hamilton, R. \& Hewer, P. (2002). Consumer Attitude and the Usage and Adoption of HomeBased Banking in the United Kingdom. International Journal of Bank Marketing, 20(3), 111-121.

Ibrahim, E. E. Joseph, M. \& Ibeh, K. I. N. (2006). Custotyr's Perception of Electronic Service Delivery in UK Retail Banking Sector. International Journal of Bank Marketing, 24(7), 475-493.

Johnson, G. \& Scholes, K. (1993). Exploring Corporate Strategy. Hemel Hempstead: Prentice Hall.

Joseph, M. \& George, S. (2003). An Empirical Evaluation of US Bank Customer Perceptions of the Impact of Technology on Service Delivery in the Banking Sector. International Journal of Retail and Distribution Management, 31(4), 190-202.

Khan, M. A. (2010). An Empirical Study of Automated Teller Machine Service Quality and Customer Satisfaction in Pakistani Banks. European Journal of Social Sciences, 13(3), 333-344.

Lai, V. S. \& Li, H. (2005). Technology Acceptance Model for Internet Banking: An Invariance Analysis. Information \& Management, 42(2), 373-386.

Leblanc, G. (1990). Customer Motivation: Use and Non-Use of Automated Banking. International Journal of Bank Marketing, 8(4), 36-40.

Leonard, M. \& Spencer, A. (1991). The Importance of Image as a Competitive Strategy: An Exploratory Study in Commercial Banks. International Journal of Bank Marketing, 9(4), 36-40.

Lewis, B. R. Ordledge, J. M. \& Mitchell, V. (1994). Service Quality: Students' Assessment of Banks and Societies. International Journal of Bank Marketing, 12(4), 3-12.

Marshall, J. \& Heslop, L. (1988).Technology Acceptance in Canadian Retail Banking: A Study of Consumer Motivations and Use of ATMs. International Journal of Bank Marketing, 6(4), 341-41.

Merrilees, B. (2002). Interactivity Design as the Key to Managing Customer Relations in Ecommerce. Journal of Relationship Marketing, 1(3), 111-126.

Meyer, T. (2006). Banking Online Boosts and Curbs Customer Loyalty. Frankfurt am Main: Deutsche Bank Research. http://www.dbresearch.com/pdf (Accessed 25th April, 2011).

Mouawad, M. \& Kleiner, B. (1996). New Developments in Customer Service Training. Managing Service Quality, 6(2), 49-56.

Moutinho, L. \& Brownlie, O. T. (1989). Customer Satisfaction with Banks Services: A Multidimensional Space Analysis. International Journal of Bank Marketing, 9(5), 23-30.

Pyun, C. Scaggs, L. \& Nam, K. (2002). Internet Banking in the US, Japan and Europe. Multinational Business Review, 10(2), 73-81.

Ranaweera, C. \& Prabhu, J. (2003). The Influence of Satisfaction, Trust and Switching Barriers on Customer Retention in a Continuous Purchasing Setting. International Journal of Service Industry Management, 14(4), 374-95.

Rugimbana, R. \& Iverson, P. (1994). Perceived Attributes of ATMs and their Marketing Implications. International Journal of Bank Marketing, 12(2), 30-35.

Schneider, B. \& Bowen, D. E. (1995). Wining the Service Game. Boston, MA: Harvard Business School Press.

Solomon, M. R., Surprenant, C. J. Czepiel, A. Gutman, E. G. (1985). A Role Theory Perspective on Dyadic Interactions: The Service Encounter. Journal of Marketing, 49(1), 99-111.

Stanley, T. \& Moschis, G. (1983). The ATM-Prone Consumer: A Profile and Implications. Journal of Retail Banking, 5(1), 45-51.

Stevens, R. Martin, R. Carter, P. \& Cogshell, D. (1986). A Comparative Analysis of Users and Non-Users of Automatic Teller Machines. Journal of Retail Banking, 8(1/2), 71-78.

Suh, B. \& Han, I. (2002). Effect of Trust on Customer Acceptance of Internet banking. Electronic Commerce Research and Applications, 1(3/4), 247-263.

Tan, M. \& Thompson, S. H. (2000). Factors Influencing the Adoption of Internet Banking. Journal of the Association of Information Systems, 1(1/5), 1-42.

Tong, Y. K. (2009). A study of E-Recruitment Technology Adoption in Malaysia. Industrial Management \& Data Systems, 109(2), 281-300.

Wu, J. H. \& Wang, Y. M. (2007). Measuring ERP Success: The Key-Users' Viewpoint of the ERP to Produce a Viable IS in the Organization. Computers in Human Behavior, 23(3), 1582-1596.

Yavas, U., Bilgin, Z. \& Shemwell, D. (1997) Service Quality in the Banking Sector in an Emerging Economy: A Consumer Survey. The International Journal of Bank Marketing, 15(6), 217-23.

Zhu, Z., Scheuermann, L. \& Babineauz, B. J. (2004). Information Network Technology in the Banking Industry. Industrial Management and Data Systems, 104(5), 409-417. 